\title{
Research Paper Economic analysis of mint cultivation in Madhepura district of Bihar
}

\author{
- Ram Suresh Sharma, Sanjay Kumar, Deepak Kumar and R. K. Srivastava
}

See end of the paper for authors' affiliations

Correspondence to :

Ram Suresh Sharma

Technology and Business Development Division, CSIR-Central Institute of Medicinal and Aromatic Plants, Lucknow (U.P.) India

Email: rs.sharma@cimap. res.in

\section{Paper History :}

Received : 30.06.2020;

Revised :03.07.2020;

Accepted : 05.08.2020
ABSTRACT : The present study of mint variety-CIM-Karnti demonstrated for cultivation of Madhepura district of Bihar. Mint is an essential oil bearing plant. Oil and its derivatives are extensively used in food, pharmaceutical, perfumery and flavouring industry. During the study period, 55 farmers of mint cultivation have been demonstrated on the farmer's field of five villages under Madhepura district of Bihar during 2018-19. The primary data were collected from the selected farmer's field. Simple analytical tools and technique has been used for data analysis and for carried out the cost of cultivation according different cost concepts. The multiple linear production function was used to evaluate the resource use efficiency in the production of mint. It was observed that medium level adoption of mint cultivation has been found higher followed by high and low level adoption. The total cost of cultivation and gross return has been found Rs. 52,804/- and Rs. 1, 59,268/- ha ${ }^{-1}$, respectively. The net return on cost $\mathrm{A}_{1}$, C, Rs. 1,06,464/- and Rs. 90,640/-ha ${ }^{-1}$. The benefit cost ratio has been observed 2.02 and 1.32 at cost $\mathrm{A} 1$ and Cost $\mathrm{C}$, respectively. The independent variables like sucker and nursery raising, manures and fertilizers and distillation charges were positive indicating significant impact on the returns from mint crop in the study area. Thus, profitable returns through cultivation of mint may attract large number of farmers to cultivate this crop to enhance their income and employment in the study area with integrated farming traditional crops.

KEY WORDS : Economics of mint, Cost, Returns, Adoption

How To Cite This PAper : Sharma, Ram Suresh, Kumar, Sanjay, Kumar, Deepak and Srivastava, R.K. (2020). Economic analysis of mint cultivation in Madhepura district of Bihar. Internat. Res. J. Agric. Eco. \& Stat., 11 (2) : 127-131, DOI : 10.15740/HAS/IRJAES/11.2/127-131. Copyright@2020:Hind Agri-Horticultural Society. 